\title{
MODO DE PRODUÇÃO E REVOLUÇÃO: LUKÁCS E MÉSZÁROS
}

\author{
MODO DE PRODUCCIÓN Y REVOLUCIÓN: LUKÁCS Y MÉSZÁROS
}

\section{MODE OF PRODUCTION AND REVOLUTION: LUKÁCS AND MÉSZÁROS}

Sergio Lessa ${ }^{1}$

\begin{abstract}
Resumo: Argumenta-se que para Lukács e Mészáros a categoria modo de produção apenas faz sentido se articulada com a concepção marxiana do trabalho como fundante do ser social e esta, por sua vez, é a chave da proposta revolucionária que retiram de Marx.
\end{abstract}

Palavras-chave: Modo de Produção; Trabalho; Ser Social; Karl Marx.

Resumen: Se argumenta que para Lukács y Mészáros la categoría modo de producción apenas hace sentido si articulada con la concepción marxiana del trabajo como fundante del ser social y esta, por su vez, es la clave de la propuesta revolucionaria que quitan de Marx.

Palabras-clave: Modo de producción; Trabajo; Ser Social; Karl Marx.

Abstract: This article argues that for Lukács, as for Mészáros, the category mode of production makes sense if articulate with the Marxian conception of labour as social being's founding category, which is the touchstone of the revolutionary proposal that both thinkers find in Marx.

Key-words: Mode of production; Labour; Social being's; Karl Marx.

István Mészáros publicou na virada do século Para Além do Capital, desde então referência para a discussão da complexa questão da transição para uma sociedade não regida pelo capital. Ainda que seja muito cedo para uma avaliação definitiva da obra - as investigações mal começaram -, talvez o tempo não converta em absurdo afirmar que sua recuperação das teses de Marx acerca da necessidade histórica da transição - a concepção do capital enquanto causa sui, um "sujeito sem sujeito" (subjetless subject); a impossibilidade ontológica de o sistema do capital enfrentar as verdadeiras causas ("enquanto causas") de sua desumanidade e, por fim, o antagonismo ontológico do comunismo com toda e qualquer a forma de controle hierárquico do trabalho (não apenas o capitalista, como também o conhecido nas sociedades “pós-revolucionárias" do leste europeu) é o nódulo articulador não apenas de Para além do capital, mas de toda a vasta obra de Mészáros.

Tal persistência na investigação de um mesmo complexo de problemas por décadas exibe um forte paralelo com a evolução de seu mestre, Gyorgy Lukács. Este também cultivou ao longo de pelo menos cinco décadas o complexo de problemas que o conduziria à Estética e à Ontologia. Desde o período de Moscou, mais precisamente desde sua leitura dos Manuscritos de 1844, sua evolução intelectual foi decisivamente marcada pelo que Guido Oldrini, em um texto até hoje fundamental (OLDRINI, 2002), 
denominou de sua "virada ontológica". Isto é, sua abordagem da obra de Marx enquanto uma nova concepção de mundo que supera a a-historicidade da essência humana que vigorou desde Parmênides até Hegel. Ainda que tenha levado cerca de três décadas para Lukács amadurecer essa "virada" até a Ontologia, e ainda que apenas no início de 1960 tenha descoberto a "bela palavra ontologia" (no sentido que passa a empregá-la até seu falecimento), post festum é perceptível como sua evolução foi orientada pela "viragem ontológica".

Mészáros, por seu lado, divergindo de seu mestre - e com a história a lhe dar razão convencido de que a transição soviética não poderia conduzir ao comunismo, evoluiu até identificar as “sociedades pós-revolucionárias" como uma nova forma histórica de regência do capital. Liberto de todas as ilusões e compromissos teóricos e ideológicos típicos daqueles que, como Lukács, postulavam ser a ordem soviética um tipo qualquer de socialismo (socialismo de Estado, socialismo com deformações, socialismo real, etc.), pode desenvolver sua tese decisiva: a superação do capital requer não apenas a superação da ordem capitalista ocidental, mas também da ordem surgida nas "sociedades pósrevolucionárias". Não é apenas uma formação social específica a ser superada, mas sim todo o "sistema do capital".

Não há dúvidas - ainda porque é explicitamente reconhecido por Mészáros - do quanto Para Além do Capital é devedora de Lukács. Muitas das categorias ontológicas decisivas estão presentes nos dois autores, por vezes de modo idêntico, outras vezes com Mészáros realizando importantes desenvolvimentos (por exemplo: o trabalho enquanto categoria fundante do ser social comparece de modo idêntico nos dois autores; já a temporalidade recebe em Mészáros um tratamento que desenvolve significativamente as considerações de Lukács). E não há dúvidas, também, o quanto os dois pensadores se distanciam quando a questão é a transição para o comunismo. Há aqui um enorme campo de investigações que, repetimos, mal se iniciaram e que possivelmente ocuparão boa parte da próxima década dos que estão nelas empenhados.

Outro paralelo também pode ser encontrado entre Mészáros e seu mestre. Tal como a Ontologia de Lukács foi inicialmente recebida com enorme desconfiança - e mesmo desprezo - pela porção majoritária da esquerda européia (principalmente depois da publicação do artigo "Observações ao companheiro Lukács" de seus ex-discípulos na revista italiana Aut-Aut, em 1977 (FEHER et al., 1977)), assistimos em nossos dias a um fenômeno um tanto parecido com Para Além do Capital. De uma leitura superficial e preconceituosa, Agnes Heller, Ferenc Feher, entre outros, postularam ser a Ontologia nada mais que a tentativa de salvar o stalinismo elevando-o a um patamar metafísico. É conhecido como as inverdades e interpretações incorretas por parte dos ex-discípulos de Lukács levaram quase uma década e meia de intensos esforços de intelectuais do porte de Nicolas Tertulian, Guido Oldrini, Césares Cases, Vitoria Franco, entre outros para serem completamente desacreditadas, a ponto de, hoje, serem mencionadas apenas como curiosidade ou exemplo a não ser seguido. Analogamente, entre nós, hoje, encontramos julgamentos peremptórios do texto de Mészáros a partir de uma leitura primeira que não permite que se vá além de avaliações ligeiras e superficiais. É assim, por exemplo, que por vezes Mészáros é acusado de ser althusseriano ou estruturalista (logo ele que redigiu em 1970 o clássico $A$ teoria da alienação 
de Marx!) por afirmar ser o capital um "sujeito sem sujeito". Ainda que a "morte do sujeito" tenha sido um dos temas mais caros ao estruturalismo tardio dos anos de 1970-80, tal tese nada tem em comum com a expressão marxiana "sujeito sem sujeito" recuperada por Mészáros. Neste trata-se apenas e tão somente da tese segundo a qual enquanto a humanidade não superar o sistema do capital, a história continuará sendo predominantemente determinada pelas necessidades da reprodução do capital e não pelas autênticas necessidades humanas. Trata-se, sem mais nem menos, da tese de Marx de que o capitalismo faz parte, ainda, da "pré-história da humanidade", aquele longo período no qual, como a história não é feita conscientemente pela humanidade, esta é arrastada por processos alienantes que se potencializam até chegar ao fetichismo da mercadoria dos nossos dias. Outras vezes é acusado de ser idealista por postular a força material das idéias nos processos de transição, por salientar - como poucos autores em nossos dias a importância da consciência para os processos revolucionários. Ou, ainda, é rotulado de visionário e ingênuo ao postular o fim do Estado e da política na ordem comunista e por postular não haver na ordem soviética nenhum grama de "socialismo".

Não é preciso muito para se perceber que, sendo corretas tais críticas, o denso e rico texto de Para Além do Capital não passaria de um amontoado de teses desconexas e sem qualquer articulação geral. Exatamente o oposto, todavia, é a verdade: o texto é internamente articulado e coerente e requer um esforço interpretativo que não pode ser esgotado em alguns pouquíssimos anos, para não dizer em semanas, de uma leitura aligeirada. Novamente, tal como ocorreu com Lukács, quando as enormes contribuições e novidades trazidas pela Ontologia necessitaram de décadas de árduo trabalho para simplesmente demonstrar a falsidade dos preconceitos cultivados pelas leituras rápidas e superficiais, é bem provável que sejam necessários anos de investigações para se demonstrar o óbvio, qual seja, que Para Além do Capital explicita o pleno significado de suas categorias a partir de seu todo e que, por isso, as abordagens superficiais perdem o seu fundamental. Em tais leituras a parte substitui o todo e buscam-se atalhos para se evitar o esforço de conquista de todo o texto: tais os julgamentos rápidos, peremptórios, possuem enorme possibilidade de serem brutais equívocos.

É uma pena que, depois de termos tanto acumulado em nosso país na leitura e investigação do último Lukács, depois de tantos anos de experiência acumulada no combate - muito mais ideológico do que interpretativo, por vezes - para a recuperação das teses ontológicas centrais do último Lukács (julgamento que se tenha delas à parte), repitamos muito dos mesmos equívocos interpretativos passados. Mas, enfim, dado o momento em que vivemos, talvez isso seja inevitável e aos que se dedicam ao estudo de Para Além do Capital talvez não reste alternativa senão aproveitar a experiência da geração de Oldrini, Tertulian, Vitoria Franco, Constanzo Preve, Mészáros, etc.: paciente e persistentemente demonstrar por uma leitura imanente as incorreções dos argumentos que pretendem substituir o estudo sério da obra de Mészáros por julgamentos e avaliações superficiais, incorretas e distantes do texto; interpretações que tendem a revelar muito mais o que tais intérpretes pensam do mundo do que, de fato, o conteúdo do texto em exame. Afinal de contas, o preconceito é um pré-conceito justamente porque é revelador da substância do preconceituoso muito mais do que do mundo em que se vive. 
Feitas essas ponderações introdutórias e solicitando a generosidade do leitor para um texto que certamente será superado pelo andamento das investigações, queria aproveitar a ocasião para uma primeira aproximação de um tema importante: qual seria a confluência e eventuais diferenças entre Lukács e Mészáros quando da relação entre modo de produção, trabalho e revolução? Tanto quanto pudemos compreender desses autores - e a esta altura das investigações, repetimos - não restam muitas dúvidas de que a categoria modo de produção apenas faz sentido se articulada com a concepção marxiana do trabalho enquanto categoria fundante do ser social e esta, por sua vez, é a pedra de toque da proposta revolucionária de Lukács e Mészáros. Isso não é tão difícil de ser percebido, ainda que as articulações ontológicas entre trabalho e modo de produção sejam bastante ricas, complexas. Sendo o trabalho o fundante da sociabilidade, o trabalho primitivo é fundante da sociabilidade primitiva; o trabalho escravo funda o escravismo e o trabalho servil e o trabalho proletário fundam, respectivamente, os modos de produção feudal e o capitalista. É nessa articulação que a categoria da reprodução social, tal como investigada por Lukács em sua Ontologia, ocupa o lugar central.

Decisivos nessa articulação ontológica entre o fundante e o fundado do ser social são dois aspectos. O primeiro deles é que o trabalho é fundante do ser social porque, ao realizar o intercâmbio orgânico com a natureza, gera possibilidades e necessidades que não podem mais ser nem atendidas nem exploradas no intercâmbio com o ser natural. Ou seja, o trabalho insere o mundo dos homens em um processo reprodutivo que requer, pela sua própria essência, a criação de novos complexos sociais (distintos do trabalho) para explorar as novas possibilidades e para atender às novas necessidades geradas predominantemente na esfera do trabalho. Os novos complexos sociais, por sua vez, também geram novas necessidades e possibilidades que podem exigir o desenvolvimento de tais complexos, a criação de outros complexos ou, ainda, o desenvolvimento da totalidade social de modo mais direto e imediato. Em cada caso, as necessidades e possibilidades geradas tanto na esfera do trabalho quanto aquelas produzidas nos demais complexos sociais fazem parte do complexo processo que é o "afastamento das barreiras naturais" (Marx) ou, para dizer o mesmo com outras palavras, o devir-humano dos homens. Portanto, se o trabalho é a categoria fundante do ser social, se as formas históricas particulares do trabalho (primitivo, escravo, servil, proletário, etc.) são fundantes das formações sociais particulares (sociedade primitiva, escravismo, feudalismo, capitalismo, etc.), disso não resulta que a totalidade social possa ser redutível ao trabalho. Pelo contrário, entre a totalidade social e o trabalho há uma relação entre o que é fundante (o trabalho) e o que é fundado (a totalidade social). E isso faz com que qualquer identidade entre esses dois termos seja a mais completa impossibilidade ontológica. Esse é o primeiro aspecto importante dessa relação que nos parece ser comum a Lukács e Mészáros.

O segundo aspecto nos remeterá mais diretamente ao nosso tema: o fato de ser o trabalho a categoria fundante faz com que o modo historicamente particular em que se realiza o intercâmbio com a natureza funda as possibilidades de desenvolvimento de inteiros períodos históricos, justamente os modos de produção. Novamente, os modos de produção não são redutíveis ao trabalho (como argumentamos); todavia, o fato de o trabalho cumprir a função social decisiva da reprodução social (a conversão da natureza em meios de produção e de subsistência) faz com que as necessidades e possibilidades que 
surgem nessa esfera tenham um peso e uma influência tendencialmente maior na reprodução social que aquelas geradas nos outros complexos sociais. Por exemplo, a impossibilidade da existência das classes sociais no período primitivo é fundada pelas peculiaridades do trabalho primitivo; os enormes obstáculos ao desenvolvimento de tecnologias no escravismo são fundados pelas particularidades do trabalho escravo; o beco sem saída a que o desenvolvimento das forças produtivas conduziu o feudalismo tem no trabalho servil seu momento fundante; no capitalismo maduro é o trabalho proletário que funda a contradição antagônica entre o pleno desenvolvimento das forças produtivas e a propriedade privada (com tudo que está a ela ontologicamente associado: o Estado, a política, o casamento monogâmico, as classes sociais, etc.), e assim por diante. As tendências mais universais do desenvolvimento histórico são fundadas pelo trabalho em geral; as tendências particulares de desenvolvimento de cada modo de produção são fundadas pela forma historicamente específica com que o trabalho comparece em cada momento e, ainda, a reprodução social sendo a consubstanciação da totalidade das mediações em cada caso. Nesse contexto, os limites e possibilidades históricas das formações sociais particulares relacionamse predominantemente com as potencialidades e limites históricos das formas particulares de trabalho que os fundam - analogamente a como é o trabalho que funda as possibilidades e limites de desenvolvimento ao ser social em sua máxima universalidade.

É por essa razão que a história da humanidade é composta por uma sucessão de modos de produção: na medida em que o intercâmbio orgânico com a natureza vai se transformando, como resultado do devir-humano dos homens, as relações sociais vão também se desenvolvendo tanto para atender às novas necessidades geradas nesse processo como, também, para explorar as novas possibilidades históricas ao desenvolvimento social nele produzidas. As transições entre os modos de produção correspondem aos saltos ontológicos no interior do desenvolvimento do intercâmbio com a natureza e, aqui, para evitar equívocos, talvez seja bom repetir: isso não significa que a história da humanidade seja redutível ao intercâmbio com a natureza. É exatamente do oposto que se trata: por mais importante que seja o desenvolvimento do trabalho - e ele certamente o é -, seu peso decisivo na reprodução social tem por fundamento o fato de que gera possibilidades e necessidades que não podem ser atendidas pelo próprio trabalho. Em poucas palavras, o fato de o trabalho ser fundante é a razão de a totalidade social não ser redutível ao trabalho e, analogamente, de a história humana não se reduzir ao desenvolvimento do intercâmbio dos homens com a natureza. Portanto, a correspondência entre os saltos ontológicos no intercâmbio homem/natureza e o desenvolvimento dos modos de produção é tudo, menos direta ou imediata; sempre tem por mediação decisiva o complexo que Lukács, em sua Ontologia, denominou reprodução social - como já dissemos. Esse é, também, um aspecto que parece haver ampla convergência entre Mészáros e Lukács.

\section{Trabalho, modo de produção e classes sociais}

Sendo o trabalho a categoria fundante, na relação entre a produção e a distribuição é a primeira que predomina sobre a segunda. Em outras palavras, a produção determina a distribuição porque o que 
será produzido já contém o modo como será distribuído. Na sociedade primitiva, o parco afastamento das barreiras naturais fazia com que a única possibilidade de intercâmbio com a natureza fosse a coleta do já pronto a ser consumido (sementes, raízes, frutas, pequenos animais, carniça, insetos, etc.). Naquelas condições, a produtividade era tão baixa que o rendimento do tempo gasto na exploração do trabalho era inferior ao rendimento de igual tempo de coleta: a exploração do homem pelo homem era uma impossibilidade histórica absoluta. Produzia-se o que era mais urgente para a sobrevivência a partir das possibilidades imediatas ofertadas pela natureza. A sociedade tinha, por isso, necessariamente que ser um agrupamento nômade de poucos indivíduos; as ferramentas tinham que ser descartáveis porque não era possível carregá-las; a proporção entre adultos produtivos, crianças, velhos e mulheres grávidas tinha que ser precisamente controlada para maximizar as possibilidades de sobrevivência e, ao mesmo tempo, minimizar os riscos da carência de alimentos, etc. Tal sociedade não conhecia nem o Estado, nem o dinheiro, nem o Direito - como seria possível a existência de tais complexos sociais se todos os indivíduos precisavam dedicar praticamente a totalidade de suas capacidades à coleta dos alimentos? Além disso, qual a necessidade de tais complexos em sociedades que viviam da mão para a boca, sem qualquer possibilidade significativa de acumulação?

O trabalho primitivo, portanto, funda uma sociabilidade que desconhece as classes sociais, a exploração do homem pelo homem (portanto, a propriedade privada), o casamento monogâmico (o patriarcalismo) e o Estado. Era o que Marx e Engels denominaram de "comunismo primitivo". E, enquanto tal forma peculiar de trabalho não foi superada, a humanidade conheceu o modo de produção primitivo.

O fato de o trabalho produzir sempre necessidades e possibilidades que remetem para além do trabalho enquanto tal (parafraseando uma famosa passagem da Ontologia de Lukács) fez com que, a partir de um determinado ponto da história, o desenvolvimento cotidiano da relação do homem com a natureza passasse por um salto ontológico. O lento acúmulo da experiência no trato com a natureza, o desenvolvimento das capacidades humanas que se reflete em uma coleta que vai se tornando crescentemente sistemática e que possibilita o aumento da produtividade do trabalho, o aperfeiçoamento da divisão das tarefas no interior do bando, etc., conduziu à descoberta da semente há aproximadamente doze mil anos atrás. Com o aparecimento da agricultura, da pecuária e dos animais domésticos, a relação do homem com a natureza adquiriu uma qualidade que não possuía antes: o trabalho excedente. Em poucas palavras, pela primeira vez o indivíduo que planta e/ou cuida dos animais consegue produzir mais do que o indispensável para a sua sobrevivência imediata. Se, antes, o que se produzia era imediatamente consumido, agora há a uma nova situação, plena de novas potencialidades e necessidades. Ao invés do nomadismo, as sociedades vão se transformando em sedentárias. A produção para o consumo imediato é substituída por uma produção que deve ser armazenada e consumida ao longo do ano e, portanto, devemse desenvolver mecanismos sociais para a distribuição do produzido. Novas relações sociais, novos critérios de organização das relações entre os indivíduos, novas necessidades que antes sequer eram consideradas devem agora ser atendidas. As novas possibilidades históricas advindas com a agricultura impõem novas necessidades e abrem novos horizontes ao desenvolvimento humano; necessidades e 
horizontes antes inexistentes, frisemos.

É nesse contexto histórico que a exploração do homem pelo homem passa a ser mais produtiva do que o rendimento do próprio trabalho. Se, antes, o tempo gasto para se controlar o trabalho do indivíduo a ser explorado resultava em uma produção inferior ao que se obteria diretamente pelo trabalho próprio, agora a situação se inverte. Pela utilização das armas, antes ferramentas empregadas para a caça dos grandes animais, tornou-se possível, em um primeiro momento, fazer a guerra e se apoderar da safra acumulada. Em um segundo momento, ao invés de se destruir a aldeia, descobre-se que melhor é coletar anualmente um imposto equivalente a uma porção do produzido - mantendo a aldeia para ser novamente expropriada no ano seguinte. E, finalmente, a alternativa que se revelou a mais produtiva: conquista-se pela força das armas a aldeia a ser expropriada, matam-se todos aqueles que não são capazes de gerar trabalho excedente (velhos, crianças, mulheres, etc.) e convertem-se todos os outros em escravos. A atividade dos dominadores passou a se concentrar, agora, na organização da aplicação cotidiana da violência. Só assim é possível obrigar os trabalhadores a produzirem a riqueza daqueles que os dominam. A propriedade privada fez, pela violência, sua entrada na história da humanidade. E nem poderia ser de outro modo: está ainda para surgir uma modalidade de exploração do homem pelo homem que não se apóie na aplicação cotidiana da violência. Violência e propriedade privada são irmãs siamesas: aspectos distintos da mesma totalidade social que surge com a agricultura, que é fundada pelo trabalho excedente.

A humanidade deixou para trás o período marcado pela coleta - o modo de produção primitivo - e transitou para uma nova fase histórica que perdurou por cerca de 14 mil anos, até a Revolução Industrial (1776-1830). É este o longo período histórico em que as classes sociais foram mediação indispensável ao rápido desenvolvimento das forças produtivas e, portanto, foram uma necessidade histórica incontornável. Esse ponto é importantíssimo para nossa discussão e a ele voltaremos mais à frente: as sociedades de classe levaram ao desaparecimento de todas as sociedades que desconheciam a exploração do homem pelo homem, porque, ao concentrarem a riqueza nas mãos de uns poucos, possibilitaram que parte desta fosse investida no desenvolvimento das forças produtivas. Diferente das sociedades primitivas que consumiam toda a produção, a concentração das riquezas sociais nas mãos das classes dominantes possibilitou que uma porção importante fosse investida no desenvolvimento do comércio, do transporte, dos exércitos, etc. Desse modo, no confronto com as sociedades igualitárias terminou predominando o maior desenvolvimento das forças produtivas das sociedades de classe. Por essa única razão - e não por qualquer razão relacionada à presença de uma pretensa essência humana imutável, a-histórica - as sociedades de classe se converteram na mediação histórica indispensável ao rápido desenvolvimento das forças produtivas desde a descoberta da agricultura até a Revolução Industrial.

A fase histórica marcada pela presença necessária das classes sociais inclui o modo de produção asiático, o modo de produção escravista, o feudal e a acumulação primitiva do capital (entre os séculos XVI e XVIII). É o período histórico que vai dos grandes impérios da antiguidade no Ocidente, dos grandes impérios do modo de produção asiático (no Oriente e na América Latina), até o apogeu das grandes navegações, o desenvolvimento do mercado mundial e das manufaturas que marcou o período 
moderno. A característica marcante desse período histórico é o fato de que ao se produzir a riqueza da classe dominante já é determinada a distribuição do produzido: os trabalhadores serão expropriados pela imprescindível - aplicação cotidiana da violência por parte da classe dominante e seus auxiliares diretos (quase sempre assalariados); a riqueza produzida será convertida em propriedade privada da classe dominante que, com base nela, financiará a manutenção de todos os complexos sociais imprescindíveis à aplicação da violência sobre os trabalhadores (exército, polícia, burocracia, torturadores, Direito - o Estado, enfim).

As classes sociais receberam, então, seu estatuto ontológico acabado: são fundadas pela forma peculiar do trabalho em cada modo de produção. $O$ trabalho escravo funda o antagonismo escravos/senhores de escravos; o trabalho servil funda o antagonismo servo/senhores feudais e o trabalho proletário funda o antagonismo proletariado/burguesia. As classes sociais se distinguem pelo lugar que ocupam na estrutura produtiva da sociedade, ou seja, pela posição relativa que ocupam em relação ao trabalho no interior de cada sociedade. Cada forma histórica peculiar da classe trabalhadora (camponeses asiáticos, escravos, servos, proletários) corresponde a uma classe dominante (os mandarins e castas superiores, os senhores de escravos, os senhores feudais e a burguesia); a superação dos modos de produção é também a superação das suas classes fundamentais e, inversamente, é impossível o desaparecimento de uma delas sem o simultâneo desaparecimento da sua contrapartida histórica. Assim, o desaparecimento dos escravos é também o desaparecimento dos senhores; o fim da servidão é também o fim dos senhores de escravos; o fim do proletariado corresponderá ao desaparecimento da burguesia ${ }^{2}$.

Modo de produção e trabalho estão, portanto, necessariamente articulados. É o fato de o trabalho ser fundante do ser social que faz com que cada uma de suas particularizações seja fundante dos distintos modos de produção. Isso esboçado (esboçado, pois sequer mencionamos o complexo da ideologia e todos os problemas decorrentes dos processos de alienação), podemos passar à parte final deste artigo: o que há no trabalho proletário, aquele funda o capitalismo contemporâneo que faz com que o modo de produção capitalista maduro seja o primeiro a conhecer a possibilidade histórica da superação da sociedade de classes? E, ao nos dirigirmos a esse tópico, nos aproximamos do terreno em que as primeiras diferenças importantes entre Lukács e Mészáros começam a se manifestar.

\section{Luta de classes e luta pela superação da propriedade privada}

Em 1865 Marx concluiu uma palestra a sindicalistas ingleses com a famosa palavra de ordem: "Em vez do lema conservador de: 'Um salário justo para uma jornada de trabalho justa!', [a classe trabalhadora] deverá inscrever na sua bandeira esta divisa revolucionária: 'Abolição do sistema de trabalho assalariado'”(MARX, 1979, p. 99). Desde o surgimento da exploração do homem pelo homem conhecemos milhares de anos de luta de classes; contudo, apenas recentemente elas puderam se elevar contra o fundamento mesmo das classes sociais e, portanto, contra o fundamento ontológico da própria luta de classe: a propriedade privada. As revoltas dos escravos no período antigo, as revoltas dos camponeses e servos na era medieval, bem como as revolta de camponeses, artesãos, pequenos burgueses 
e burgueses no período moderno possuíam limites históricos muito estreitos. Eram marcadas pelas utopias de retorno à sociedade sem exploração do homem pelo homem; outras vezes pela elevação dos "em revolta" da condição de explorados à condição de classe dominante, pelas propostas "comunistas" utópicas (no sentido de não ter lugar na história) do final da Idade Média ou, então, pelas propostas contratualistas modernas. Isso se deve à característica particular, própria, do trabalho excedente surgido com a agricultura. Encurtando uma longa história, o excedente gerado pelo trabalho escravo, servil ou artesão (aquele do período da acumulação primitiva, entre a decadência das guildas medievais e as manufaturas complexas) não era suficiente para o atendimento de todas as necessidades de todos os indivíduos do planeta Terra. Se todo o produzido fosse distribuído da forma mais igualitária possível, a produção não atenderia todas as necessidades de todos os indivíduos: a vida humana não havia ainda se libertado da carência. Nessa circunstância histórica, a sociedade que tenderá a predominar sobre as outras será aquela capaz de concentrar a riqueza possibilitando o investimento no desenvolvimento das forças produtivas: as sociedades de classe, como já vimos.

A persistência da carência - uma peculiaridade ontológica do trabalho escravo, servil e artesão impunha aos humanos limites muito estreito às lutas de classe. A impossibilidade da superação da sociedade de classes tornava uma impossibilidade histórica a superação da propriedade privada. Por isso as revoltas não podiam se voltar contra o próprio fundamento da exploração do homem pelo homem.

A Revolução Industrial reverteu de modo radical essa situação. O desenvolvimento do mercado mundial garantiu, por um lado, um mercado consumidor e fontes de matérias primas virtualmente infinitas. Por outro lado, as transformações sociais provocadas pela crise do modo de produção feudal associadas ao desenvolvimento das relações mercantis levaram à concentração nos centros urbanos de uma enorme de força de trabalho. A confluência desses dois fatores com o capital comercial acumulado desde o século XVI pelas potências imperialistas européias tornou lucrativa a introdução de máquinas na produção. Estavam dadas as condições históricas para o que passou à história como Revolução Industrial.

De modo análogo a como a descoberta da agricultura possibilitou à humanidade superar a coleta em direção à expropriação do trabalho excedente, a Revolução Industrial também subverteu a reprodução social. Rompeu o limite corpóreo do ser humano (ter duas pernas, dois braços, uma determinada capacidade física, etc.) para a produção. Para qualquer padrão até então conhecido, a expansão da produtividade do trabalho foi espantosa. Pela primeira vez a humanidade adquiriu a capacidade de produzir mais do que o necessário para atender a todas as necessidades de todos os indivíduos do planeta Terra. A carência, que sempre marcou a história da humanidade, é, finalmente, superada pela Revolução Industrial. Teve início, então, o período da abundância.

Relembremos o afirmado logo acima: a carência associada ao trabalho excedente tornava as classes sociais uma necessidade histórica. Com a Revolução Industrial, a humanidade superou a carência e adentrou à abundância. A sociedade capitalista reúne, por isso, pela primeira vez, propriedade privada e abundância. E, nessas novas circunstâncias, a propriedade privada se converteu no principal obstáculo ao desenvolvimento das forças produtivas. Vejamos como. 


\section{Propriedade privada e crise estrutural do capital}

Até aqui, Lukács e Mészáros, tanto quanto eu consigo entender, estão fundamentalmente juntos. Com a questão da transição à sociedade sem classes, as primeiras diferenças mais evidentes começam a surgir. Mészáros salienta com muito mais força, sublinha mais intensamente, a categoria "tempo disponível" que o faz seu mestre.

O desenvolvimento das relações mercantis que conduziu do modo de produção feudal ao capitalismo desenvolvido redundou em um fenômeno inédito. Por um lado, pelas mediações que Marx expôs minuciosamente ao tratar da acumulação primitiva, a conversão da sociedade em uma "enorme coleção de mercadoria" (MARX, 1983, p. 46) tornou o mercado a mediação universal da vida humana, ao mesmo tempo em que elevou as forças produtivas a tal patamar de desenvolvimento que superou a carência das sociedades pré-capitalistas. A abundância (isto é, a capacidade de se atender a todas as necessidades de todos os indivíduos) deixou no passado a carência. Uma sociedade de classes (que correspondia às necessidades históricas do período que associava trabalho excedente e carência, lembremos) inaugurou um outro período histórico no qual o trabalho excedente ganhou uma nova qualidade: produz a abundância. Dadas as condições históricas em que se deu esse salto ontológico, a produção assumiu a forma particular da produção capitalista. E sua grande peculiaridade, na comparação com os modos de produção anteriores, é que a sua forma de riqueza, o capital, se reproduz imediatamente (aqui, o imediatamente é decisivo, já veremos o porquê) pela mais-valia, a qual - pela sua própria essência - apenas se realiza se o produto for vendido. A realização da mais-valia, portanto, requer que seu valor seja traduzido em uma quantidade de dinheiro, o preço, e que a mercadoria seja vendida/comprada no mercado. O mercado passou a ser uma mediação decisiva para que as forças produtivas capitalistas possam se reproduzir. E a relação entre o valor e o preço tem na relação entre a oferta e a procura uma sua determinação importante.

$\mathrm{Na}$ acumulação primitiva, com a carência em vigor, a procura tendia a ser maior do que a oferta, garantido um patamar de preços condizente com a acumulação do capital. Essa situação se inverteu com a passagem ao século XIX. A abundância fez com que a oferta fosse tendencialmente superior à procura, os preços tendessem a cair, a taxa de lucro tendesse a diminuir por toda a economia e o capitalismo, maduro, passasse a viver sucessivas crises de superprodução3. Por isso, para que a reprodução do capital prossiga, é decisivo o desenvolvimento de relações sociais que convertam a abundância em carência pelo maior desperdício possível: a sociedade burguesa vai desenvolvendo complexos sociais que potencializem a perdularidade de todo o sistema. Todos os complexos sociais passam a ser permeados, de modo mais ou menos evidente, mas sempre predominante, por essa necessidade intrínseca ao sistema do capital. Das guerras mundiais às guerras "localizadas", da produção de alimentos ao mundo fashion, da produção de remédios aos produtos culturais, em todos os complexos sociais essa necessidade do capital se impõe. Se a abundância não for convertida em carência pela destruição, o sistema do capital não poderá mais se reproduzir. É isto que Mészáros, em uma formulação insuperável, denominou de "produção destrutiva": a 
produção da abundância, a maior riqueza humana historicamente possível, é convertida pelas mediações das alienações que brotam do capital nas misérias de nossos dias.

De crise em crise, de perdulário em perdulário, o pleno desenvolvimento humano - que se expressa condensadamente no desenvolvimento das forças produtivas, no afastamento das barreiras naturais - encontra hoje na propriedade privada seu principal obstáculo. Vivemos o antagonismo entre o trabalho proletário o pleno desenvolvimento das forças produtivas na era da abundância.

\section{Vejamos a razão desse fato}

A incompatibilidade ontológica entre a abundância e o modo de produção capitalista tem no trabalho proletário seu fundamento último. Este se distingue dos modos de expropriação do trabalho précapitalistas também (portanto, não apenas) por realizar o intercâmbio orgânico com a natureza pela mediação da mais-valia. Transformar a natureza para produzir mais-valia significa, por um lado, que o produto terá que ser trocado no mercado por um preço e, como vimos, a presença da abundância tendencialmente derruba os preços abaixo do tempo de trabalho socialmente necessário para produzi-las. Nessa situação, a única alternativa ao sistema do capital é intensificar a extração da mais-valia em última análise reduzindo os custos com os salários pela adoção de máquinas e equipamentos cada vez mais desenvolvidos. Altera-se, assim, a "composição orgânica do capital": os custos dos equipamentos e instalações (capital constante) tendem a proporcionalmente se elevar frente aos salários (capital variável), com o que o aumento do capital investido cresça desproporcionalmente ao incremento da lucratividade. $\mathrm{O}$ sistema do capital como um todo tende a se tornar cada vez menos lucrativo. Isso por um lado. Por outro lado, a adoção de tecnologias e equipamentos cada vez mais desenvolvidos tende a promover o aumento da produção concomitante ao aumento do desemprego. Este, como observou Marx, subsume o trabalho ao capital com uma força maior do que a da corrente com que Hefaísto prendeu Prometeu ao rochedo. Pressionados pela queda do preço da força de trabalho decorrente do crescimento da concorrência pelos empregos, ao trabalhador resta individualmente poucas oportunidades para a reação ao aumento de sua exploração. Como resultado, o aumento da produção da riqueza conduz à concentração da mesma nas classes dominantes e à generalização da miséria, ao mesmo tempo em que a contradição entre a abundância e o crescimento da forças produtivas capitalistas tende a se intensificar.

Esta é a "lei geral da acumulação capitalista" em seus traços mais elementares e este é o seu fundamento: o trabalho proletário. A permanência do trabalho proletário implica, com rigorosa necessidade histórica, a vigência da "lei geral da acumulação capitalista": a produção converte-se em "produção destrutiva" quando o sistema do capital atinge sua crise estrutural, na formulação de Mészáros. A alternativa a esse estado de coisas não está em qualquer alteração da ordem que preserve seu fundamento, isto é, o trabalho proletário. Para que a "lei geral da acumulação capitalista" seja superada é imprescindível a superação do trabalho proletário.

Se essas observações, até aqui, podem ser encontradas também em Lukács, em Mészáros são exploradas com maiores detalhes e de modo mais aprofundado. O que se segue, todavia, é quase que 
exclusivamente Mészáros - sobre as questões que trataremos a seguir encontrei na Ontologia apenas poucas, difusas e dispersas indicações.

\section{O trabalho associado e o comunismo}

Desde os primeiros momentos das sociedades de classe até nossos dias, o desenvolvimento da mercadoria coincidiu com a sucessão dos modos de produção. A evolução do escravismo ao feudalismo, deste ao capitalismo, é, em parte, a história de como a mercadoria se converteu, após milhares de anos e sucessivas formações sociais, na relação universal entre os humanos. Quando a sociabilidade finalmente se apresentou como uma "enorme coleção de mercadoria", o seu fetichismo passou a ser integrante da substância dos indivíduos e da totalidade social - com as devidas mediações em cada caso.

A exploração do trabalho com o capitalismo atingiu seu ápice: não há modalidade de expropriação do trabalho excedente que possa superar o trabalho abstrato, pois não há forma de exploração que possa ser mais eficiente do que a compra da força de trabalho pelo seu valor de troca. Não há, também, possibilidade de retorno aos modos de produção pré-capitalistas, nem o trabalho escravo nem o servil podem ser alternativas ao atual antagonismo entre o desenvolvimento das forças produtivas e o capital.

A alternativa nem é um retorno ao passado nem a reforma do presente, mas a superação do trabalho proletário pelo trabalho associado: este é o conteúdo histórico da revolução proletária. Trabalho associado e revolução proletária mantêm uma íntima relação: o segundo apenas poderá vir a ser pela superação do trabalho proletário. O que requer, evidentemente, a eliminação de todos os complexos sociais voltados à aplicação cotidiana da violência: o Estado, a propriedade privada e o casamento monogâmico. Por isso o programa estratégico da revolução proletária é a superação da exploração do homem pelo homem, das classes sociais, do Estado e do casamento monogâmico.

Discutimos com maiores detalhes a relação entre a abundância e o comunismo, com clara inspiração em Mészáros, em “Comunismo: do que se trata” (LESSA, 2005), e por isso não é agora necessário que nos estendamos sobre esse aspecto. Sem a abundância, a carência associada ao trabalho excedente tornará inevitável o retorno às classes sociais e a todas as suas mazelas - como a tragédia soviética e das outras "vias ao socialismo" demonstraram e demonstram cotidianamente. Com a abundância, ao contrário, a reorganização da reprodução social ao redor do "tempo disponível" (deixando na lata do lixo da história o tempo de trabalho socialmente necessário) terá por pressuposto a livre organização dos trabalhadores para a definição consciente do que será produzido e como ocorrerá a produção. No cerne da conversão da natureza nos meios de produção e subsistência se alojarão as necessidades humanas libertas do fetichismo da mercadoria. Na produção teremos as consequências positivas do desenvolvimento omnilateral dos indivíduos: o livre desenvolvimento de cada um será a condição indispensável ao pleno desenvolvimento da sociedade. A relação social chamada mercadoria, após atingir seu máximo desenvolvimento, será eliminada da vida humana: o valor de troca será um fóssil 
da nossa história tal como, na expressão de Engels, é hoje o machado de bronze. Teremos, então, transitado a um novo modo de produção: o comunismo.

Assim como nas transições de um modo de transição a outro, no passado, também essa transição ao comunismo será um processo de superação e de manutenção (a famosa Aufhebung). Foi, como já vimos, o revolucionário desenvolvimento das forças produtivas por obra e graça do capital que abriu as possibilidades históricas do comunismo. Será a partir desse patamar, e nunca aquém dele, que o comunismo se estruturará. A continuidade, todavia, será secundária frente à nova essência que se afirmará na reprodução social: sem a propriedade privada, qual a serventia do Estado e do casamento monogâmico? Qual pode ser o fundamento das classes sociais superada a exploração do homem pelo homem? Radicalmente, um novo horizonte de possibilidades e necessidades objetivas e subjetivas se abrirá à humanidade; de tal modo radicalmente novo que seria hoje tão fútil tentar prever o que será o modo de produção comunista como seria inútil ter solicitado a um servo medieval descrever São Paulo no século XXI.

\section{Comunismo e trabalho associado}

Tal como o trabalho proletário funda o modo de produção capitalista, o trabalho associado é fundante do comunismo. A passagem ao comunismo, nesse sentido, é a transição para uma nova modalidade do intercâmbio orgânico do homem com a natureza e, nisso, a transição ao comunismo tem muito em comum com as passagens de um modo de produção a outro no passado. Todavia, diferente do passado, essa transição implica a superação da propriedade privada, com tudo o que a ela está historicamente associado: o Estado, as classes sociais e o casamento monogâmico. Não será a passagem de uma forma de exploração do homem pelo homem a uma outra forma, mais desenvolvida, como conhecemos anteriormente, mas a constituição de uma sociabilidade com uma qualidade radicalmente nova. Na produção não terá lugar nada de semelhante à reprodução da propriedade privada da classe dominante e as relações sociais não mais comportarão qualquer forma de poder. Ao mesmo tempo, e por causa disso, a contraposição no interior das substâncias dos indivíduos entre uma porção genérica e outra privada ficará no passado 4 . Nem a sociedade nem os indivíduos serão mais os mesmos.

É nesse momento que as pessoas, na maior parte das vezes, identificam em Marx traços de utopia: como seria possível uma sociedade sem poder?!

Antes da Revolução Inglesa do século XVII, mas em especial da Revolução Francesa, identificava-se a vida civilizada com a existência de monarcas. Sem monarcas, como seria possível a vida civilizada? Ainda que o monarca fosse ruim, sem ele seria pior, seria o caos. Sabemos hoje que isso não é verdade. Todavia, a tratar do poder (e de suas manifestações mais cotidianas, o Estado, a política e o casamento monogâmico) reagimos como a humanidade reagia no passado quando contemplava os monarcas. Sem o poder, esse modo hierárquico de organizar a vida social que impõe à reprodução social todas as condições imprescindíveis para a manutenção das classes dominantes, a maioria de nós consegue apenas imaginar como alternativa o caos e a barbárie. Livres, ninguém mais trabalharia; sem a ordem 
imposta pela lei, as relações sociais degenerariam em uma guerra civil de todos contra todos: retornaríamos à barbárie.

Há que se reconhecer que as pessoas têm alguma (mas apenas alguma) razão em pensarem desse modo. Sem o Estado, sem as relações de poder, nenhuma sociedade de classe, muito menos a capitalista, poderia se reproduzir por um dia que fosse. Como as relações sociais articuladas ao redor da propriedade privada requerem a mediação cotidiana da violência, elas converteram os homens, para sermos breves, em lobos do próprio homem. A totalidade das relações sociais articulada ao redor da violência converteu cada indivíduo em um galo (sem qualquer machismo) de briga, e a sociedade em uma enorme rinha. Todas as relações sociais, inclusive a relação mais íntima do indivíduo consigo próprio, são mediadas pela concorrência. A essência humana, por ser o conjunto das relações sociais, converteu os indivíduos das sociedades de classe em animais mesquinhos, concorrenciais, egoístas, aguerridos: individualistas. Comportam-se como se fossem bestas na rinha e são avaliados socialmente como locomotivas: o quanto produzem por unidade de tempo (MARX, 1979). O desenvolvimento dessa humanidade (isto é, dessa sociedade e dos indivíduos que a compõem) não poderá levar, por si só, à sociedade emancipada da propriedade privada. O desenvolvimento do capitalismo trará sempre e apenas mais e mais capitalismo: a humanidade pode até mesmo - capitalisticamente - se destruir. Essa porção do preconceito de que sem poder não há civilização tem - alguma - razão de ser: de fato, sem a aplicação cotidiana da violência, principalmente pelo Estado, a civilização da sociedade de classe não poderia existir.

A porção equivocada está em assumir que a barbárie em que o capitalismo se converteu é o máximo da civilização. Que, para além dessa civilização, poderia existir apenas o caos. O equívoco está em se assumir que nosso presente será eternamente o futuro! Se isso fosse válido para a história da humanidade, estaríamos ainda vivendo no período primitivo. O presente da história humana, qualquer que seja ele, tem como uma das suas principais características a de que jamais se repetirá. E já vimos a causa fundamental dessa situação: o trabalho, a categoria fundante do ser social, remete sempre para além de si mesmo ao produzir novas necessidades e possibilidades, lançando a história humana em um processo de incessante e contínua produção do novo. Se o presente é o que é hoje, é certo que não o será no futuro.

A passagem ao comunismo, contudo, não pode ser o mero prosseguimento evolutivo do que hoje somos. A violência que impera na vida cotidiana (a violência que é a propriedade privada) apenas pode ser superada por um salto ontológico que revogue, no próprio fundamento da vida social, no trabalho, a necessidade por essa mesma violência. E isso significa, de modo absoluto, a "expropriação dos expropriadores". Ou seja, que na própria organização da transformação da natureza nos meios de produção e de subsistência - o ato mais básico, fundante da reprodução do mundo dos homens - a produção de riqueza mude inteiramente, não apenas de forma, mas principalmente de conteúdo histórico. A riqueza tem que deixar de ser a riqueza da classe dominante para se converter na riqueza humana, no desenvolvimento mais pleno, livre e completo, das capacidades humanas em todas as suas dimensões.

Essa é uma alteração tão radical e completa que até mesmo algo tão básico quanto o valor de uso será modificado profundamente. $\mathrm{O}$ fato de, no capitalismo, a riqueza ser a produção da mais-valia, faz com que o valor de uso da principal mercadoria, a força de trabalho, seja reduzido à sua capacidade de 
gerar mais-valia. Com o advento do capitalismo, por isso, o valor de uso passou por uma transformação substancial de seu conteúdo: sua principal função na reprodução da sociedade capitalista passou a ser a função de portador do valor de troca. E, na medida em que o fetichismo da mercadoria se generalizou como predominante das relações sociais, o próprio conteúdo do valor de uso se transformou para se converter em portador de valor de troca. Desse modo, por exemplo, na saúde, se produz um remédio ou se adota um procedimento médico padrão desde que ele possa ser lucrativo: o principal valor de uso está em ser mediação para a acumulação do capital, com todas as implicações necessárias.

Em tudo diferente, no modo de produção comunista a categoria econômica central será o tempo disponível. Ou seja, tendo em vista a possibilidade e/ou a necessidade da produção de um determinado produto, coletivamente a humanidade avaliará se é preferível gastar-se a energia, força de trabalho, recursos naturais, etc., para a produção do novo objeto ou se, pelo contrário, é preferível ficar com mais tempo disponível para se viver e, portanto, que aquele produto não será produzido. Certamente, como já argumentamos em "Comunismo, do que se trata?", isso apenas seria possível em uma sociedade da abundância. É a abundância que cria as condições objetivas imprescindíveis à superação da exploração do homem pelo homem. Dada essa condição, todavia, as novas possibilidades e necessidades inerentes à abundância apenas poderão ser atendidas e exploradas com a alteração radical do intercâmbio orgânico com a natureza, o trabalho. E, fazendo curta uma longa história, essa alteração tem o seu momento fundante na substituição do tempo de trabalho socialmente necessário pelo tempo disponível no coração da estrutura produtiva.

Portanto, do mesmo modo como ocorreu com todas as transições de um modo de produção a outro, também a transição ao modo de produção comunista implica numa alteração da forma particular do intercâmbio orgânico com a natureza. Do trabalho proletário passaremos ao trabalho associado. Da economia organizada para produzir a mais-valia, passaremos à economia organizada para produzir aquilo que os trabalhadores livremente organizados decidirem conscientemente. De uma reprodução social que necessita imperativamente da violência cotidiana para impor aos trabalhadores a produção da propriedade privada da classe dominante, transitaremos para uma reprodução social ordenada para possibilitar que a humanidade tire o máximo proveito da abundância. O desenvolvimento omnilateral dos indivíduos será a condição insuperável do desenvolvimento do gênero humano.

Diferente do passado, contudo, essa transição de um modo particular do trabalho a outro trará uma enorme novidade. Deixará de ser a transição de uma forma de propriedade privada menos desenvolvida para uma outra mais desenvolvida; deixará de ser a passagem para uma nova forma de reprodução social com maior capacidade de produzir mercadorias; deixará de ser o surgimento de uma forma mais desenvolvida e aperfeiçoada de aplicação da violência na vida cotidiana; tudo isso para ser a transição para uma sociedade na qual as crianças irão aos museus e, lá, darão risadas (ou ficarão pasmas) ao serem informadas que a humanidade se matou aos milhões pela posse de um pedacinho de papel ou de metal que chamavam - nós, os "bárbaros" - de dinheiro. Será a transição para uma sociedade sem qualquer hierarquia de controle, sem Estado, propriedade privada, classes sociais e casamento monogâmico: a sociedade comunista. Será a saída, da humanidade, de sua "pré-história". 


\section{Conclusão}

Assim como o trabalho funda a passagem do natural ao social, o trabalho primitivo funda o modo de produção primitivo, o trabalho servil funda o modo de produção feudal, o trabalho proletário funda o modo de produção capitalista e, se Deus for grande e de fato escrever por linhas tortas, o trabalho associado fundará o modo de produção comunista. O conceito de modo de produção está, portanto, estreitamente articulado ao trabalho enquanto categoria fundante do ser social.

Cada modo de produção conta com a organização societária que brota da sua modalidade de intercâmbio orgânico com a natureza. $\mathrm{O}$ trabalho primitivo funda uma sociedade sem classes porque ainda não conhece o trabalho excedente; por sua vez, a confluência da carência com o trabalho excedente está na origem das sociedades de classe. O trabalho escravista funda a sociedade composta por senhores de escravos, assalariados e escravos; o trabalho servil funda a ordem social formado pelos senhores feudais e os servos (os assalariados também estão presentes, ainda que em um número bem menor que em Roma); o trabalho abstrato do proletariado funda a sociedade burguesa: capitalistas e operários, com as "classes de transição" (como denominava Marx em O 18 brumário) servindo de auxiliar na expropriação dos operários. Superada a carência pela Revolução Industrial, abre-se a transição para além das sociedades de classe. Tal como o desenvolvimento das forças produtivas exigiu o aparecimento das classes sociais após a Revolução Neolítica, a abundância requer a superação das mesmas para que o desenvolvimento humano (o devirhumano dos homens) possa prosseguir em sua plenitude. Esta é a necessidade histórica da revolução proletária. Se e quando tal necessidade será atendida é algo que depende da evolução histórica futura. Podemos ir ao socialismo ou à barbárie - "se tivemos sorte”, acrescentaria Mészáros, pois poderemos terminar com a extinção da humanidade.

Trabalho e modo de produção estão, em Lukács e Mészáros, intimamente articulados. As classes sociais são fundadas pela particularidade histórica do trabalho excedente em cada período; analogamente, a possibilidade e a necessidade de sua superação têm suas raízes nas particularidades históricas do trabalho proletário.

A abundância, fundada pela conversão do trabalho artesão e servil em trabalho proletário, graças ao complexo processo histórico da Acumulação Primitiva e da Revolução Industrial, abre novas possibilidades e novas necessidades históricas à humanidade. Nas novas condições do intercâmbio orgânico com a natureza, a abundância se impõe como uma situação insuperável do mesmo modo como a carência foi insuperável por milhares de anos entre a Revolução Neolítica e o início do século XIX. Não há como, no modo de produção capitalista desenvolvido, a produção não ser muito maior do que a necessidade: esta é uma determinação ontológica insuperável dos nossos dias. Nessas condições, a propriedade privada, as classes sociais, a exploração do homem pelo homem, o Estado, o Direito, a política, o casamento monogâmico, o dinheiro, o mercado, o individualismo burguês, numa lista que poderia prosseguir, se convertem em principal obstáculo para o desenvolvimento posterior das próprias forças produtivas e, portanto, para o avanço do processo de humanização dos humanos (o devir-humano dos homens). A superação da propriedade privada é, assim, uma necessidade histórica tão inescapável em 
nossos dias quanto, no passado, foi sua mediação para o mais rápido desenvolvimento das forças produtivas.

Essas são em linhas gerais, e de forma muito introdutória, o que nos parece haver de continuidade entre a Ontologia de Lukács e Para além do capital de Mészáros, ao se tratar da relação entre modo de produção e trabalho. É certo que o desenvolvimento das investigações trará novos elementos e possibilitará compreender melhor a relação entre os dois grandes pensadores. Hoje, todavia, parece-nos razoável adiantar, mesmo que do modo mais provisório, que seriam essas as articulações fundamentais entre eles no que concerne ao tema que aqui examinamos.

\section{Referências}

BRAVERMAN, H. Trabalho e capital monopolista. Rio de Janeiro: Zahar, 1981.

FEHER, F. et al. Annotazione sull'ontologia per il compagno Lukács. Aut-Aut, Milano, n. 157-158, p. 2141, 1977.

LESSA, S. A emancipação humana e a defesa dos direitos. Serviço Social e Sociedade, São Paulo, v. 90, p. 3556, 2007.

LESSA, S. Comunismo, do que se trata?. In: GALVÃO, A. et al (Org.). Marxismo e o socialismo no século XXI. Campinas: Xamã, 2005.

LOJKINE, J. A revolução informacional. [S.1.]: Cortez, 1995.

MALLET, S. La nouvelle classe ouvrière. Paris: Éditions du Seuil, 1963.

MARX, K. A questão judáica. Rio de Janeiro: Lambert, 1969.

MARX, K. Miséria de la Filosofia. Moscou: Progressio, 1979.

MARX, K. O Capital. São Paulo: Abril Cultural, 1983. v. 1.

NAGEL, J. Trabalho colectivo e trabalho improdutivo na evolução do pensamento marxista. Lisboa, 1979. no Prelo.

OLDRINI, G. Em busca das raízes da ontologia (marxista) de Lukács. In: PINASSI, M. O.; LESSA, S. Lukács e a atualidade do marxismo. São Paulo: Boitempo, 2002.

POULANTZAS, N. Classes in contemporary capitalism. Londres: Verso, 1985.

SCHAFF, A. A sociedade informática. São Paulo: Unesp, 1990.

TONET, I. Educação, cidadania e emancipação humana. Ijuí: Unijuí, 2005.

TONET, I. Liberdade on democracia?. Maceió: Edufal, 1999.

\footnotetext{
Notas

${ }^{1}$ Bolsista de Produtividade em Pesquisa 1D. Doutorado em Ciências Sociais pela Universidade Estadual de Campinas, Brasil (1994). Adjunto IV da Universidade Federal de Alagoas, Brasil. Professor do Departamento de Filosofia - UFAL. Membro da editoria da revista Crítica Marxista. Site <WWW.sergiolessa.com>.Email: sergio_lessa@yahoo.com.br

2 Ainda que isso seja óbvio, talvez seja importante um pequeno parênteses para lembrar como, nos debates contemporâneos acerca das classes sociais, o desaparecimento do proletariado é afirmado na enorme maioria das vezes sem que sequer seja cogitado o desaparecimento da burguesia, como encontramos, por exemplo, em Adam Schaff (1990), Lojkine (1995), Mallet (1963), Braverman (1981), Poulantzas (1985), Nagel (1979) em meio a muitos outros. Como se fosse possível a superação de uma das classes fundamentais de qualquer modo de produção sem a superação, simultânea, da outra classe fundamental e, consequentemente, do próprio modo de produção.
} 
${ }^{3}$ Superprodução! Que ironia: uma sociedade, como a capitalista, que cria miséria de modo tão seguro quanto o Sol nascer a leste todas as manhãs, cria uma superprodução. Como é possível haver produção em demasia enquanto ainda houver uma única pessoa carente?

${ }^{4}$ A contraposição entre citoyen e bourgeois é típica na crítica de Marx às individualidades burguesas (MARX, 1969). Ivo Tonet explorou exaustivamente essa temática em Tonet, 2005 e 1999. Também em Lessa, 2007. 